\title{
Pengembangan Permainan Scrabble Kimia sebagai Media Pembelajaran pada Materi Struktur Atom Kelas X SMA/MA
}

\author{
D Mustika ${ }^{1^{*}}$ and Bayharti ${ }^{1}$ \\ ${ }^{1}$ Pendidikan Kimia, Universitas Negeri Padang, Jl. Prof. Dr. Hamka Air Tawar Barat, \\ Padang Utara, Sumatera Barat 25171, Indonesia \\ *dianamustika208@gmail.com
}

\begin{abstract}
Atomic structure is an abstract topic and contains factual knowledge, conceptual and procedural knowledge. While learning this chapter, students have to exercise more often. The learning media that had developed it this study can be use as exercising media for atomic structure topic. This study used Research \& Development (R\&D) type with 4-D model, they are (1) Define, (2) Design, (3) Develop, (4) Disseminate. This research was limited only in third step (Develop) with validity and practicality tests of "Scrabble Kimia" as the final product. Validity test carried out by two chemistry lectures and two chemistry teachers. Practicality test carried out by two chemistry teachers and 29 students of SMAN 1 Batang Anai. This research used quetionaries as research instrument. Data Analyzing was using Kappa Cohen formula. The result of this study indicated that "Scrabble Kimia" for Atomic Structure topic has very high category of validity with 0.82 momen Kappa value. Practicality test showed that this media has very high categories with 0.96 momen Kappa value by teachers and 0.81 momen Kappa value by students. In conclution, the "Scrabble Kimia" can be used as a learning media for atomic structure topic with very high categories of validity and practicality.
\end{abstract}

\section{Pendahuluan}

Kurikulum 2013 mengharuskan pembelajaran berpusat kepada siswa (student centered) dengan pendekatan saintifik. Pendekatan saintifik memiliki tahapan-tahapan sebagai berikut: mengamati, menanya, mengumpulkan data, mengasosiasi dan mengkomunikasikan[1]. Tahapan-tahapan pada pendekatan saintifik ini sangat diperlukan dalam memahami setiap materi kimia khususnya materi struktur atom yang bersifat abstrak.

Materi struktur atom merupakan materi yang berisi pengetahuan faktual, pengetahuan konseptual serta pengetahuan prosedural. Pengetahuan faktual pada materi ini seperti: teori atom Rutherford didasarkan pada percobaan penghamburan sinar alfa [2]. Pengetahuan konseptual pada materi struktur atom ini seperti: partikel dasar penyusun atom terdiri atas proton, neutron dan electron [3]. Pengetahuan prosedural pada materi ini yaitu tata cara pengisian elektron ke orbital berdasarkan aturan Aufbau. Berdasarkan pengetahuan tersebut maka karakteristik materi struktur atom ini memiliki banyak pengetahuan faktual, konseptual dan prosedural, sehingga siswa harus banyak mengulang serta mengerjakan latihan sebagai pemantapan materi. Meningkatkan penguasaan materi pada siswa mengenai pengetahuan faktual, pengetahuan konseptual dan pengetahuan prosedural yang telah dipelajari maka dibutuhkan adanya latihan[4].

Dari hasil wawancara dengan guru kimia di SMAN 1 Nan Sabaris, diketahui bahwa guru menggunakan media pembelajaran berupa power point dan bahan ajar yang digunakan berupa LKS dan buku paket, namun siswa belum tertarik dengan media pembelajaran yang digunakan oleh guru tersebut. Dalam proses pemantapan materi siswa mengerjakan latihan yang ada pada buku paket secara individu dan siswa sering mengalami kesulitan dalam mengerjakan latihan. Dari hasil wawancara dengan siswasiswa SMAN 1 Nan Sabaris, dimana siswa memiliki karakter yang suka bermain dan suka berkelompok.

Untuk mengatasi masalah tersebut maka diperlukan media pembelajaran yang menyenangkan, dapat 
menarik perhatian siswa dan melibatkan siswa secara aktif dan memudahkan siswa dalam mengerjakan latihan. Salah satu media pembelajaran yang dapat digunakan adalah media permainan. Media pembelajaran ini dapat meningkatkan motivasi belajar, minat belajar, dan menghilangkan kebosanan peserta didik saat proses pembelajaran berlangsung serta dapat meningkatkan pemahaman peserta didik[5]. Salah satu media pembelajaran berupa permainan yaitu permainan scrabble.

Permainan scrabble adalah permainan yang dapat meningkatkan aktifitas pemain serta dapat meningkatkan pemahaman kognitif pemain atau peserta didik[6]. Permainan sebagai media pembelajaran menciptakan pembelajaran yang aktif, menyenangkan dan meningkatkan motivasi belajar siswa. Permainan sebagai media pembelajaran juga dapat menghilangkan kebosanan siswa dalam belajar dan media ini dapat digunakan secara berulang-ulang [4].

Media permainan digunakan sebagai latihan dalam materi struktur atom. Pengulangan atau pemberian latihan berfungsi sebagai pemantapan materi atau konsep pada siswa bisa dilakukan secara individual maupun secara kelompok. Pada permainan scrabble kimia pemberian latihan ini dikerjakan secara individu oleh siswa, karena permainan bersifat kompetisi. Ditandai dengan adanya pemain yang menang dan pemain yang kalah. Penyajian permainan yang baik dan menarik perhatian siswa dapat membuat suasana belajar yang aktif dan menyenangkan [7].

Permainan yang akan dikembangkan sebagai media pembelajaran adalah permainan scrabble kimia. Permainan scrabble kimia dimodifikasi dengan menambahkan soal-soal dan kata kunci sesuai dengan materi struktur atom, sehingga dapat membantu siswa dalam meningkatkan pemahaman terhadap materi struktur atom. Permainan scrabble kimia dimainkan dengan cara siswa menyusun kata-kata yang berhubungan dengan materi struktur atom. Kemudian dilanjutkan dengan menjawab soal-soal latihan yang disediakan dalam kartu soal yang berfungsi sebagai pengganti soal latihan yang terdapat pada buku paket atau LKS. Selain menambahkan soal dan kata-kata kunci yang sesuai dengan materi, permainan scrabble kimia juga memodifikasi peraturan permainan dengan tujuan agar siswa dapat menggunakan permainan scrabble kimia dengan mudah dan menyenangkan serta menimbulkan jiwa kompetisi pada siswa tersebut. Selain itu, permainan sebagai media pembelajaran dapat menghilangkan kebosanan siswa dalam belajar dan dapat digunakan secara berulang-ulang sehingga siswa dapat bermain sambil belajar [4]. Media permainan scrabble kimia dalam pembelajaran dapat meningkatkan aktivitas belajar siswa serta motivasi belajar siswa pada materi koloid[8]. Media permainan scrabble berbasis macromedia flash pada Bahasa Indonesia dapat meningkatkan hasil belajar siswa dan keaktifan siswa dalam belajar[9].

\section{Metode}

Penelitian ini dilakukan dengan menggunakan metode penelitian dan pengembangan atau Research and Development (R\&D). Model pengembangan yang digunakan ini adalah model 4-D (four D models) yang terdiri dari 4 tahap, yaitu define, design, develop, dan disseminate. Subjek dalam penelitian ini adalah 2 orang dosen kimia FMIPA UNP, 2 orang guru kimia dan 29 orang siswa kelas X IPA di SMAN 1 Batang Anai.

Pada tahap define (pendefinisian) dilakukan untuk penetapan dan pendefinisian syarat-syarat pembelajaran. Tahap ini meliputi: (a) analisis ujung-depan, Analisis ujung depan dilakukan dengan cara mewawancarai guru kimia; (b) analisis siswa, Analisis siswa dilakukan dengan cara penyebaran angket kepada siswaa SMA; (c) analisis tugas, analisis tugas merupakan kumpulan prosedur untuk menentukan isi dalam satuan pembelajaran; (d) analisis konsep, Analisis konsep dilakukan dengan cara mengidentifikasi konsep-konsep utama pada materi struktur atom yang disusun secara sistematis dalam bentuk peta konsep; (e) perumusan tujuan pembelajaran. Tahap design (perancangan) dilakukan untuk merancang produk berdasarkan informasi yang diperoleh yang relevan terhadap hasil analisis pada tahap define. Tahap develop (pengembangan) dilakukan untuk menghasilkan media pembelajaran yang berbasis permainan scrabble pada mata pelajaran kimia yang valid serta dapat digunakan dalam proses pembelajaran siswa SMA [10]. Penelitian dibatasi hanya sampai tahap develop karena keterbatasan waktu dan biaya. Instrumen pengumpulan data penelitian yang digunakan adalah angket validitas (ditujukan kepada dosen kimia FMIPA UNP dan guru kimia SMA) dan angket praktikalitas (terdiri dari angket respon guru dan siswa). Data yang diperoleh dianalisis menggunakan formula Kappa Cohen di bawah ini.

$$
\text { momen kappa }(\kappa)=\frac{\rho_{0}-\rho_{e}}{1-\rho_{e}}
$$


Keterangan:

К $\quad=$ Momen Kappa

$\rho_{\mathrm{O}} \quad=$ Proporsi yang terealisasi

$\rho_{\varepsilon} \quad=$ Proporsi yang tidak terealisasi

Berdasarkan nilai momen Kappa yang diperoleh, dapat diambil kesimpulan berdasarkan tabel 1 .

Tabel 1. Kategori Keputusan Berdasarkan Momen Kappa (к) [11]

\begin{tabular}{c|c} 
Interval & Kategori \\
\hline $0,81-1,00$ & Sangat tinggi \\
\hline $0,61-0,80$ & Tinggi \\
\hline $0,41-0,60$ & Sedang \\
\hline $0,21-0,40$ & Rendah \\
\hline $0,01-0,20$ & Sangat rendah \\
\hline$\leq 0,00$ & Tidak valid
\end{tabular}

\section{Hasil dan Pembahasan}

\subsection{Tahap Define}

3.1.1. Analisis ujung depan. Berdasarkan hasil wawancara diketahui bahwa proses pembelajaran kimia telah dilakukan melalui penerapan pembelajaran saintifik seperti tuntutan kurukulum 2013. Guru menggunakan media pembelajaran berupa power point dan bahan ajar seperti LKS dan buku paket. Diakhir pembelajaran siswa mengerjakan latihan yang ada didalam buku teks atau bahan ajar yang disediakan oleh guru, namun siswa sering mengalami kesulitan dalam mengerjakan latihan.

3.1.2. Analisis siswa. Diperoleh data sebesar $69.05 \%$ siswa tidak berpartisipasi aktif dalam mengerjakan latihan secara individu. 99\% siswa senang berkelompok dan menyukai permainan. 100\% siswa tertarik dengan permainan scrabble kimia yang disarankan.

3.1.3. Analisis tugas. Berdasarkan hasil analisis KI dan KD 3.2 dan KD 3.3 yang terdapat pada silabus kemudian dijabarkan menjadi indikator pencapaian kompetensi. Indikator yang dikembangkan adalah: 1) menganalisis model atom Dalton, Thomson, Rutherford, Bohr dan Mekanika Gelombang. 2) menjelaskan cara penulisan konfigurasi elektron untuk setiap golongan dalam table periodik. 3) menentukan pola konfigurasi electron terluar untuk setiap golongan dalam table periodik.

3.1.4. Analisis Konsep. Konsep- konsep utama yang ada pada materi struktur atom yaitu : model atom Dalton, Thomson, Rutherford, Bohr, dan Mekanika Gelombang. Partikel dasar penyusun atom seperti elektron, proton dan neutron, isotop, isobar, isoton dan elektron valensi. Konsep-konsep ini disusun secara sistematis dalam bentuk peta konsep.

3.1.5. Analisis tujuan pembelajaran. Analisis tujuan pembelajaran digunakan untuk mengkonversikan hasil yang diperoleh dari analisis tugas dan analisis konsep menjadi tujuan pembelajaran.

\subsection{Tahap Design}

Tahap desain ini dilakukan perancangan atau pembuatan perangkat permainan scrabble kimia diantaranya yaitu papan permainan scrabble, keping huruf, kartu soal, daftar kata kunci dan aturan permainan. (a) Papan permainan scrabble dibuat dengan menggunakan aplikasi photoshop, papan permainan scrabble ini terdiri dari 225 kotak persegi yang diberi badground gambar yang berhubungan dengan materi kimia seperti gambar 1 . 


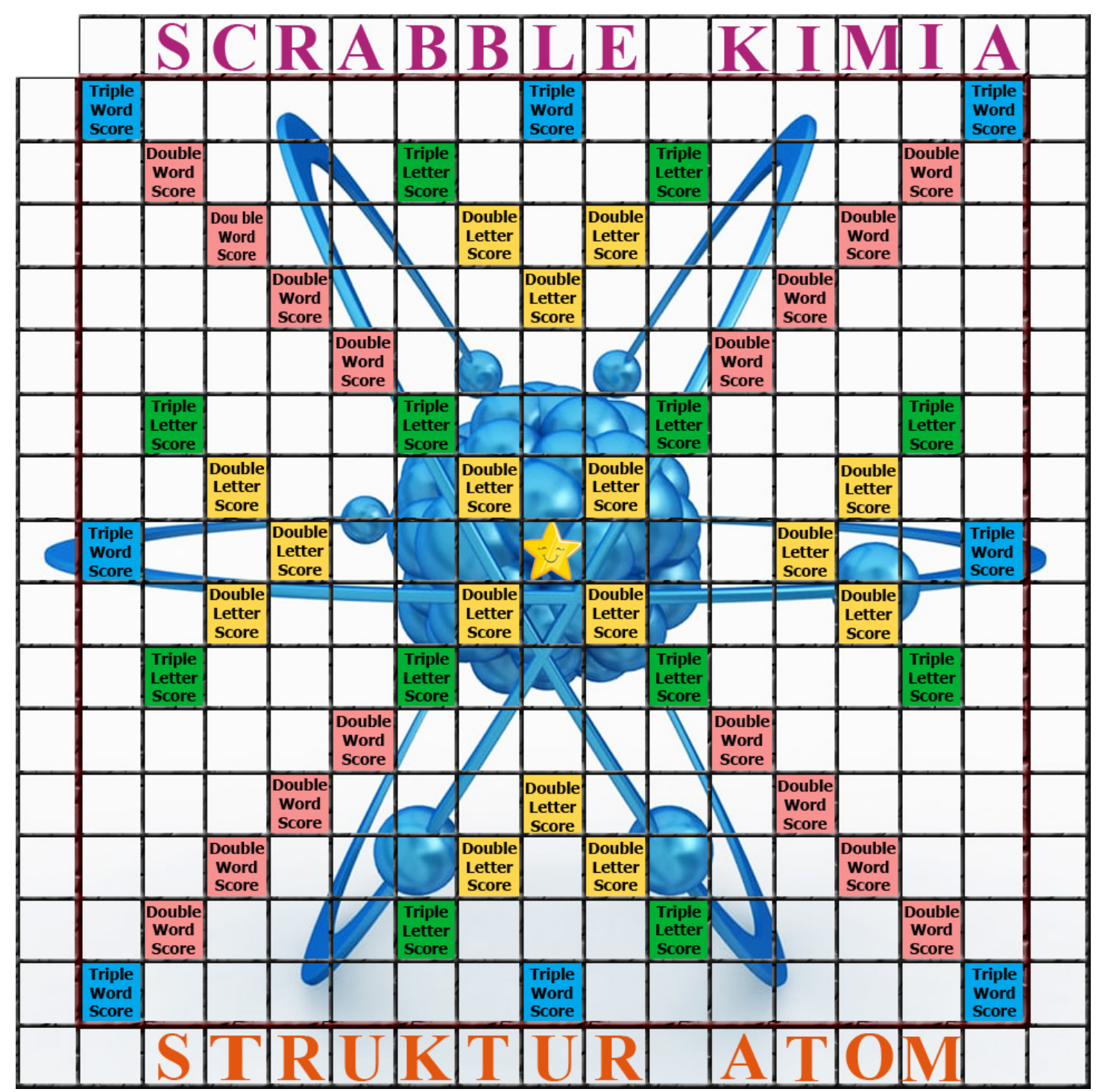

Gambar 1. Papan Scrabble Kimia

(b) Keping huruf, jumlah keping huruf yang digunakan adalah 100 buah keping huruf yang diberi poin dikanan bawah keping huruf. Poin pada keeping huruf ini dibuat berdasarkan huruf yang muncul pada materi struktur atom. Huruf yang sering muncul memiliki poin kecil sedangkan huruf yang sedikit pada materi struktur atom memiliki poin yang besar seperti gambar 2 . 


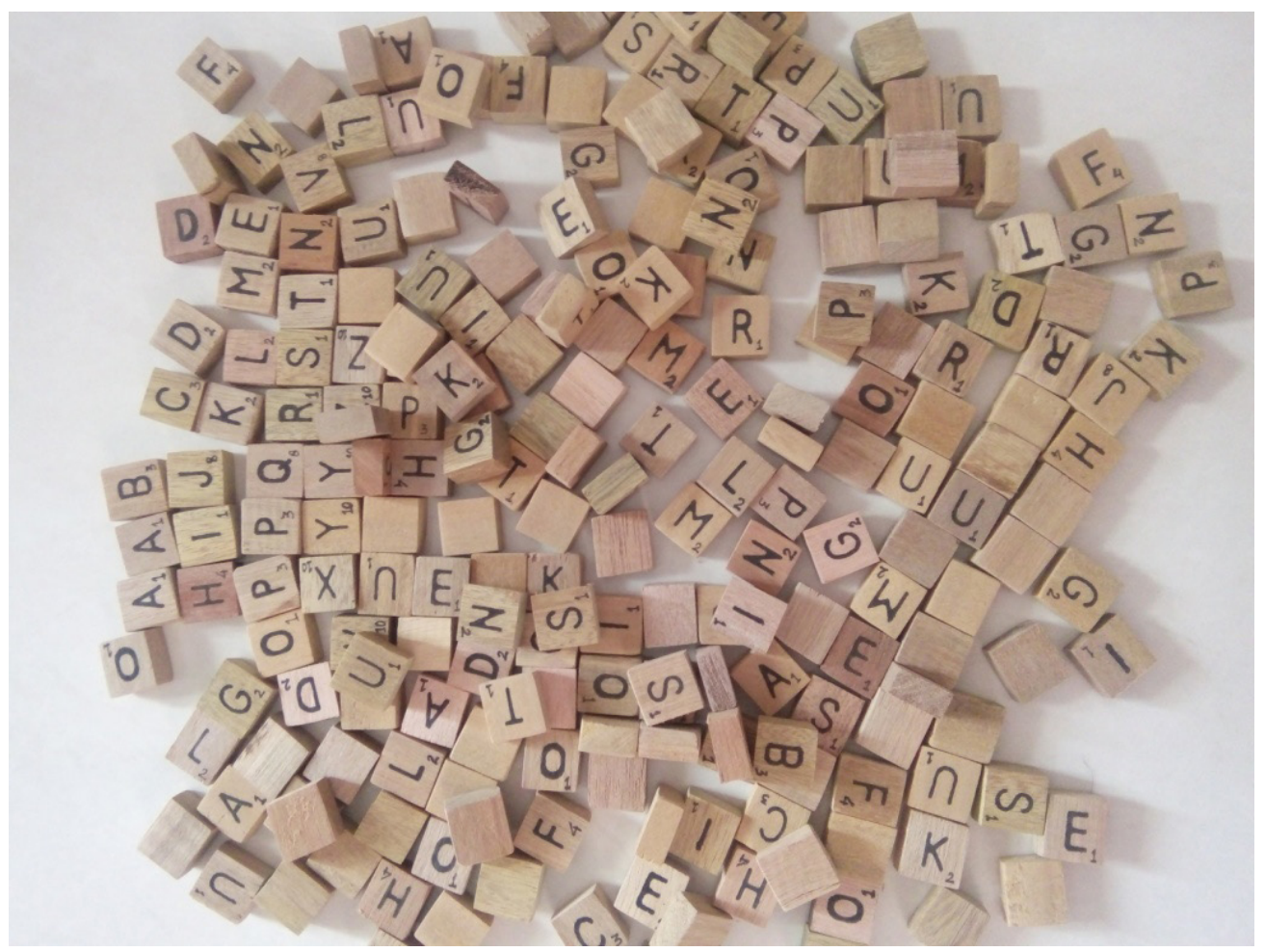

Gambar 2. Keping huruf.

(c) Kartu soal, kartu soal ini berfungsi sebagai pengganti soal latihan yang ada dibuku paket atau bahan ajar yang lain seperti gambar 3 .
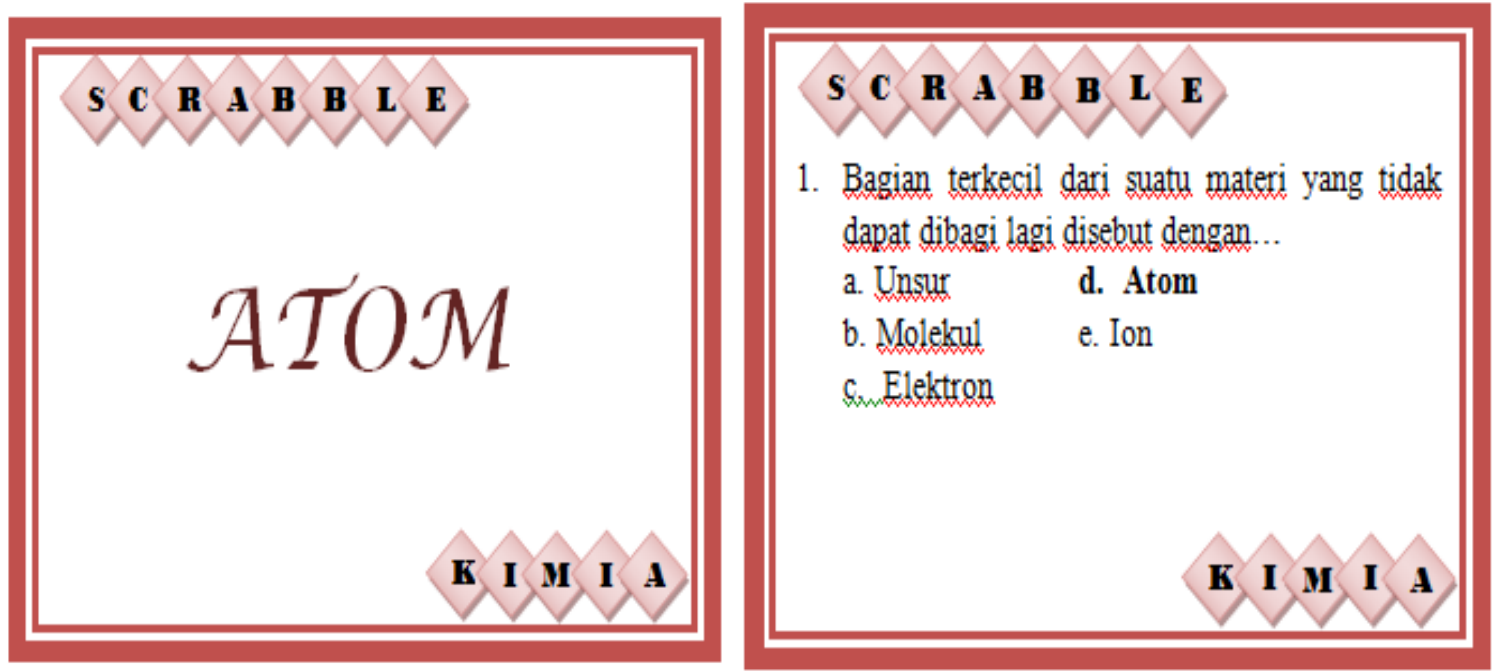

Gambar 3. Kartu soal permainan scrabble kimia.

(d) Kata kunci. Kata kunci ini berfungsi sebagai panduan bagi peserta didik untuk menyusun kata pada permainan scrabble kimia. Daftar kata kunci untuk materi struktur atom dapat dilihat pada gambar 4. 


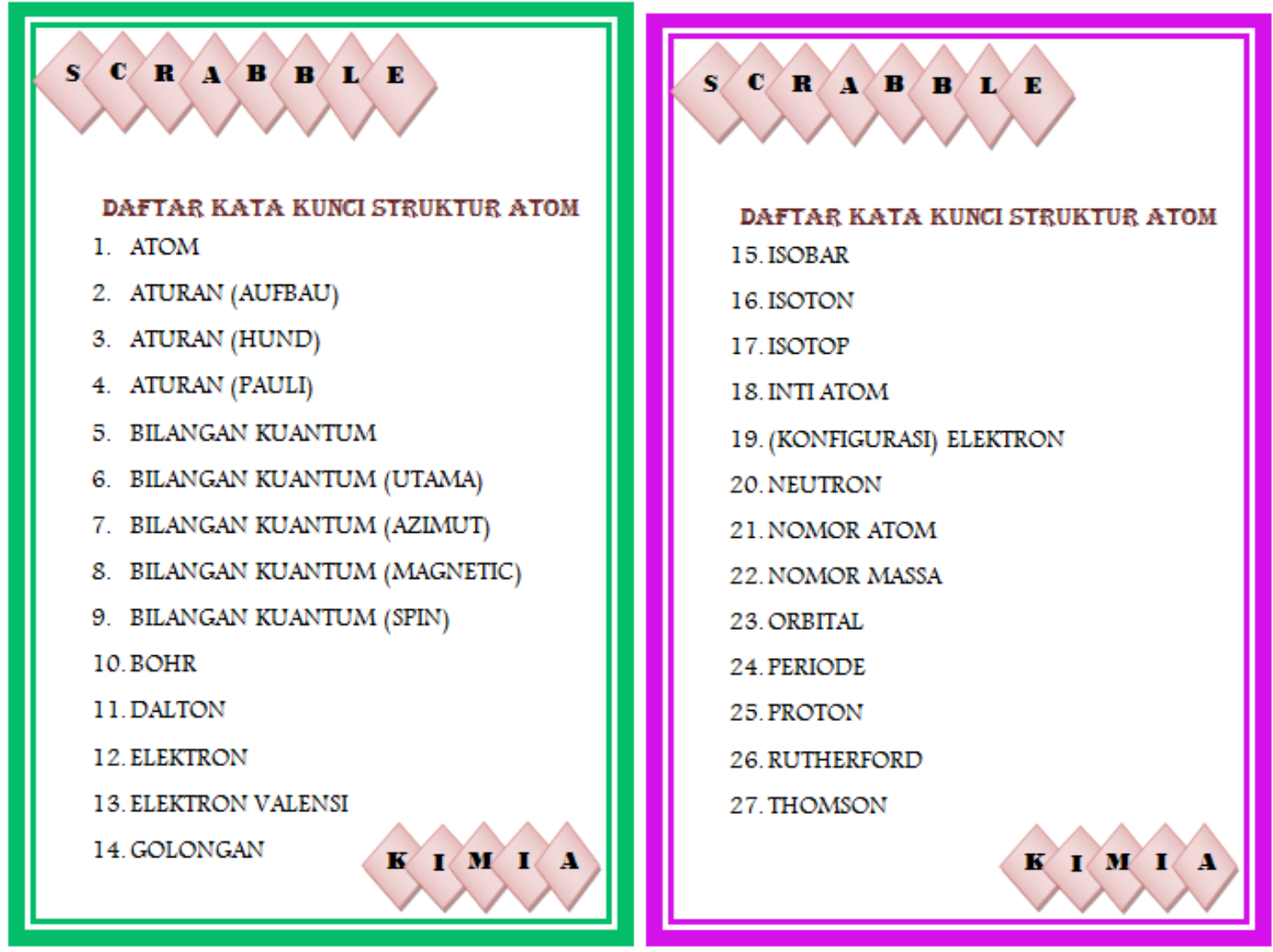

Gambar 4. Daftar kunci materi struktur atom.

(e) Aturan permainan scrabble kimia, aturan permainan dimodifikasi dari aturan permainan scrabble biasa. Aturan permainan scrabble kimia dapat dilihat pada gambar 5 berikut ini: 


\section{Aturan Permainan:}

1. Permainan dimainkan oleh 5 orang dengan satu orang sebagai koordinator permainan

2. Masing-masing pemain mengambil satu kepingan huruf untukmenentukanurutanpemain yang akanbermain berdasarkan ALFABET.

3. Masing-masing pemain mengambil 20 kepingan huruf secara acak di kantong huruf.

4. Pemain menyusun huruf yang dimilikinya menjadi sebuah kata yang sesuai dengan daftar kata kunci yang telah diberikan. Kata pertama yang disusun harus melewati tanda bintang.

5. Susunan huruf yang membentuk kata atau frasa hanya boleh disusun secara vertikal atau horizontal saja.

6. Pemain dapat menggunakan kepingan kosong sebagai pengganti huruf apa saja namun tidak mendapatkan poin. Penggunaan kepingan kosong hanya boleh digunakan maksimal 2 buah dalam satu kata.

7. Pemain yang sudah menyusun katamakapemainharusmenjawab pertanyaan yang diberikan oleh koordinator. Pemain yang dapat menjawab pertanyaan diberi poin tambahansebesar 20. Jika pemain tidak bisa menjawab,

makadijawabolehpemainselanjutnya.

8. Pemain yang sudah menyusun kata mengambil kembali kepingan huruf sebanyak huruf yang digunakan sehingga pemain kembali memiliki 20 kepingan huruf.

9. Pemain selanjutnya harus menggunakan huruf yang sudah disusun pada papan scrabble kimia sebagai bagian dari kata yang akan disusun.

10. Setiap pemain diberi waktu maksimal 2 menit untuk melakukan gilirannva. (menyusun kata dan menjelaskan kata yang disusun).

11.Jika pemain tidak dapat menyusun kata, maka pemain bisa mengganti kepingan huruf yang dimilikinva dengan huruf yang ada di kantong huruf (maksimal 5) dan melewatkan gilirannya.

12 Permainan berlangsung selama 60 menit. Permainan juga dapat berakhir lebih cepat jika tidak ada lagi pemain yang bisa membentuk kata

Gambar 5. Aturan permainan scrabble kimia.

\subsection{Tahap Develop}

3.3.1. Uji vaiditas. Validasi dilakukan oleh 2 orang dosen kimia FMIPA UNP dan 2 orang guru bidang studi kimia. Hasil yang diperoleh dapat dilihat pada Gambar 6. 


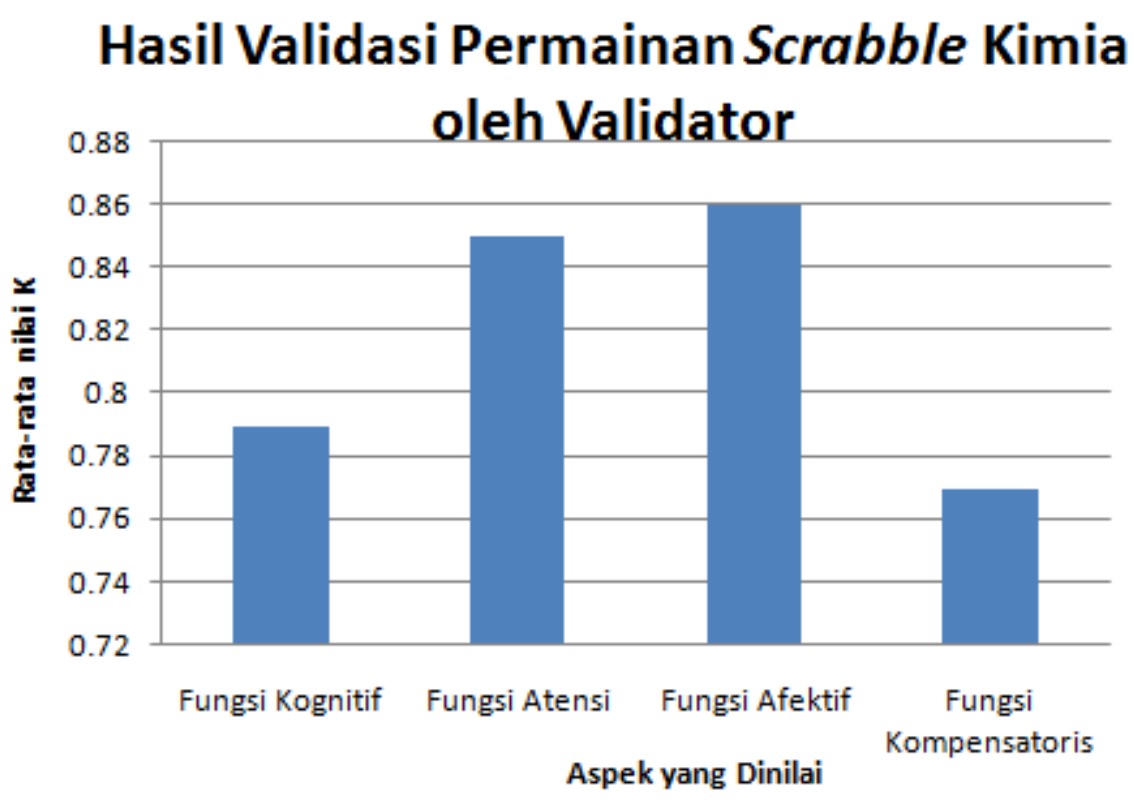

Gambar 6. Hasil analisis data validitas oleh validator.

Fungsi kognitif media pembelajaran permainan scrabble pada mata pelajaran kimia diperoleh nilai momen kappa sebesar 0.79 dengan kategori tinggi. Hal ini menandakan bahwa pertama, pengetahuan faktual yang terdapat pada kartu soal telah sesuai dengan kompetensi dasar yang ingin dicapai. Kedua, pengetahuan konseptual yang terdapat pada kartu soal telah sesuai dengan kompetensi dasar yang ingin dicapai. Ketiga, soal-soal yang terdapat pada permainan scrabble ini dibuat berdasarkan indikator pencapaian kompetensi padaa mata pelajaran kimia. Fungsi kognitif media visual dapat dilihat dari pencapaian tujuan untuk memahami dan mengingat materi yang terpesan dalam gambar[12].

Fungsi atensi media pembelajaran permainan scrabble pada mata pelajaran kimia diperoleh nilai momen kappa sebesar 0.85 dengan kategori sangat tinggi. Hal ini menunjukkan bahwa pertama, bahasa yang digunakan pada permainan scrabble sudah sesuai dengan kaidah bahasa Indonesia (EYD), yang baik dan benar, serta mudah dipahami. Kedua, gambar. Jenis dan ukuran huruf yang terdapat pada permainan scrabble jelas dan terbaca. Ketiga, warna tampilan pada permainan scrabble menarik. Fungsi atensi media visual yaitu menarik dan mengarahkan perhatian peserta didik untuk berkonsentrasi dalam proses pembelajaran yang menampilkan atau menyertai teks materi pelajaran[12].

Fungsi afektif media pembelajaran permainan scrabble pada mata pelajaran kimia diperoleh nilai momen kappa sebesar 0.86 dengan kategori sangat tinggi. Hal ini membuktikan bahwa permainan scrabble pada mata pelajaran kimia dapat menarik perhatian, menyenangkan, serta meningkatkan keaktifan peserta didik dalam mengerjakan latihan. Pembelajaran dengan perasaan yang gembira dan menyenangkan akan mempercepat proses pembelajaran, belajar dapat dioptimalkan, menempatkan peserta didik sebagai pusat sekaligus subyek pendidikan dan menghasilkan prestasi dalam belajar[13].

Fungsi kompensatoris media pembelajatan permainan scrabble pada mata pelajaran kimia diperoleh nilai momen kappa sebesar 0.77 dengan kategori tinggi. Hal ini membuktikan bahwa permainan scrabble pada mata pelajaran kimia dapat membantu memantapkan pemahaman peserta didik yang lemah karena dapat digunakan berulang-ulang. Fungsi kompensatoris dari media bertujuan agar mengakomodasi peserta didik yang lemah dan lambat dalam menerima dan memahami materi pelajaran yang disajikan dengan teks atau verbal, sehingga peserta didik mengorganisasikan informasi dalam teks dan mengingatnya kembali [12].

3.3.2. Uji praktikalitas. Praktikalitas media pembelajaran berbasis permainan scrabble pada mata pelajaran kimia dilakukan oleh dua orang guru kimia SMA dan 29 orang peserta didik kelas X IPA. Data yang diperoleh berdasarkan angket praktikalitas yang diisi oleh responden kemudian dianalisis dengan menggunakan formula Kappa Cohen. Grafik analisis nilai uji pratikalitas guru dan peserta didik dapat dilihat pada gambar 7 . 


\section{Hasil Praktikalitas Permainan Scrabble Kimia oleh Guru dan Siswa}

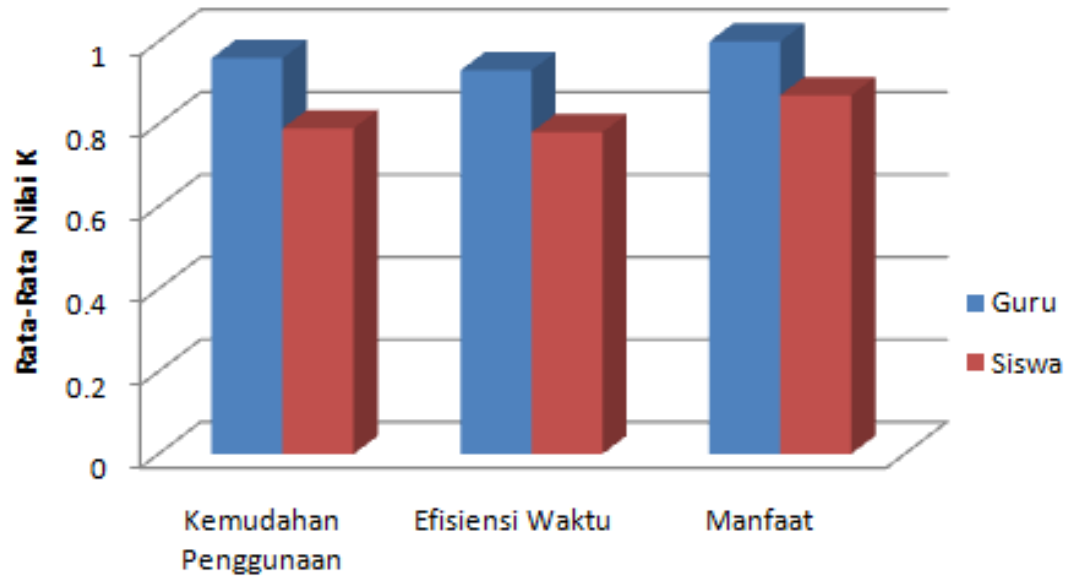

Aspek yang Dinilai

Gambar 7. Hasil analisis data praktikalitas oleh guru dan siswa.

Berdasarkan grafik diatas dapat dilihat bahwa penilaian praktikalitas permainan scrabble kimia diperoleh nilai momen kappa sebesar 0.96 (dari guru) dan 0.81(dari peserta didik) dengan kategori sangat tinggi. Nilai tersebut menunjukkan bahwa media pembelajaran berbasis permainan scrabble kimia praktis dan efisien.

\section{Simpulan}

Berdasarkan hasil penelitian yang telah dilakukan, maka dapat disimpulkan bahwa: Permainan scrabble kimia sebagai media pembelajaran pada materi struktur atom kelas X SMA/MA dihasilkan dengan menggunakan model pengembangan 4-D. Permainan scrabble kimia sebagai media pembelajaran pada materi struktur atom kelas X SMA/MA memiliki tingkat validitas dan praktikalitas yang sangat tinggi ditinjau dari fungsi media dan kepraktisan media.

\section{Referensi}

[1] Aqib, Zainal. Model-Model, Media dan Strategi Pembelajaran Tekstual (Inovatif). Bandung : Yrama Widya, 2013.

[2] Petrucci, R., H. General Chemistry: Principles and Modern Application. Toronto: Pearson Canada Inc, 2011.

[3] Syukri, S. Kimia Dasar 1. Bandung : ITB, 1999.

[4] Smaldino, Sharon E, dkk. Instruction Technology \& media for Learning. terjemahan (Arif Rahman). Jakarta: Kencana, 2012.

[5] Sudjana, Nana \& Ahmad Rivai. Media Pengajaran. Bandung : Sinar Baru Algesindo, 2011.

[6] Pengembangan Media Scrabble Huruf Hiragana untuk Meningkatkan Hasil Belajar pada Mata Pelajaran Bahasa Jepang untuk Siswa Kelas X di SMAN 22 Surabaya. Santi, Dwie aries. 2014, Vol. 01(01).

[7] Sadiman, Arief S, dkk. Media Pendidikan Pengertian, Pengembangan dan Pemanfaatannya. Jakarta: Raja Grafindo Persada, 2012.

[8] Pembuatan Media Pembelajaran Berbasis Permainan Scrabble Kimia untuk Materi Sistem Koloid Kelas XI IPA SMA. Rahayu, Puspita. Padang : s.n., 2015.

[9] Pengembangan Permainan Scrabble Berbasis Macromedia Flash untuk Materi Menulis Karangan Sederhana Bahasa Indonesia Kelas III SDN Betiting. Rahmawati, Putri Novia. 2018, Vol. 6. 2541-5468.

[10] Sugiyono. Metode Penelitian( Kuantitatif, Kualitatif dan R\&D). Bandung : Alfabeta, 2012. 
[11] Boslaugh, Sarah \& Watters, Paul A. Statistic in a Nutshell, a Desktop Quick Reference. Beijing, Cambridge, Famham, Koln, Sebastopol, Taipei, Tokyo : O'reilly, 2008.

[12] Arsyad, Azhar. Media Pembelajaran. Jakarta : Raja Grafindo Persada, 2003.

[13] Pengembangan Bahan Ajar Kimia Larutan Asam dan Basa Berbasis Chemo-Edutaiment untuk Siswa SMK TI Kelas XI. Chairiah, Albinus Sialahi dan Wesly Hutabarat. 2016. 